\title{
The Success and Failure of New Rice Fieldprint Program in Mentawai Island Regency
}

\author{
Ridwan $^{\#}$, Nusyirwan Effendi ${ }^{*}$, Faidil Tanjung $^{+}$, Asmawi $^{\$}$ \\ ${ }^{\#}$ Agricultural Sciences Study Program, Postgraduate Program, Andalas University, Padang, West Sumatra, Indonesia \\ E-mail: ridwansridwan54@gmail.com
}

*Anthropology Studies Department, Faculty of Social Science and Political Science, Andalas University, Padang, West Sumatra, Indonesia E-mail: nursyirwan@soc.unand.ac.id

${ }^{+}$Socio-economic Agriculture Department, Faculty of Agriculture, Andalas University, Padang, West Sumatra, Indonesia E-mail: faidilt@yahoo.com

${ }^{\$}$ Communication Studies Department, Faculty of Social Science and Political Science, Andalas University, Padang, West Sumatra, Indonesia. E-mail: asmawiahmadfisip@gmail.com

\begin{abstract}
The implementation of a new rice field at a print program in the district of the Mentawai Islands from 2011 to 2016 had not given satisfying results. The realization of the original rice field print in each location reached $70 \%$ at most. This was the reason why this research was implemented, which was to identify and to explain the aspects related to the success and the failure in achieving the New Rice Fieldprint in the district of the Mentawai Islands. This research used a combination method of concurrent embedded strategy, which was to combine qualitative and quantitative methods simultaneously. The primer data resource derived directly from the result of the questionnaire and interview with 13 people used as respondents. The data analysis technique used was quantitative descriptive with the help of the rating scale method, then it was analyzed by using descriptive qualitative through the help of interpretative analysis tools. This research concluded that the aspects that would be able to implement the New Rice Fieldprint program succeed were 5 aspects; included very influential elements such as qualified human resources and economic, social, and political supports in the location where the program/ policy was implemented. On the other hand, the aspects that would be able to make the program fail were also 5 aspects. The most influential elements of the failure included the limited resources such as human resources, budget, labor, material, time, and even a geographical condition of the implemented program location was painful to access by land transportation.
\end{abstract}

Keywords - geographical condition; policy; bureaucracy structure; program budget.

\section{INTRODUCTION}

Agricultural development does not only talk about natural resource management to make sure the long-term agrarian production capacity and to increase the welfare of farmers, but also as an integral part of the economic development of country and society in general [1]. Agricultural development conducted in Indonesia aims to assist the development of national economy and society and to increase the production of farm commodities to strengthen the food available so that the basic needs of the community can be fulfilled, in term of quantity, quality and affordable prices, and also can create the food security [2]-[4].

Refereed to the National Mid-Term Development Plan in 2015-2019, the Government determined some national development agenda, such as the increased food sovereignty. To achieve the objective of the agricultural development agenda, The Ministry of Agriculture issued several policies, including the increasing availability and using of land through the New Rice Fieldprint program.

Based on the data published by Food Security Board, the Ministry of Agriculture, and the World Food Program in 2015 , one of the areas have not reached the level of food security in the district of the Mentawai Islands. The food stock of citizens in Mentawai still currently depends on supplies from the mainland of West Sumatra and government assistance. The most food commodities from the district of the Mentawai Islands are bananas and taro, while rice is not widely produced in this area.

The data of the Central Bureau of Statistics records that the area of rice fields in the district of the Mentawai Islands currently covers $1,311 \mathrm{Ha}$, which is not all of them capable of producing well. This condition has encouraged the local 
government of the Mentawai Island since 2011 to issue a policy of agricultural development for paddy/ rice commodities through a New Rice Fieldprint program, agricultural machinery assistance, seedling, and fertilizer [5].

Based on statistical data from 2015, it was recorded the planting area of rice fields in the Mentawai Islands remains to remain less than $816 \mathrm{Ha}$. The policy target of the development of paddy/rice agriculture that would be achieved is to meet the needs of rice into 5,935.62 tons per year; the rice fields need approximately 1,978.54 Ha. The target expansion achievement of rice fields is expected to increase rice production and to help the realization of food security for people of the Mentawai Islands through rice commodities

The New Rice Fieldprint program in the district of the Mentawai Islands is one of the agricultural development programs. Its implementation becomes the object of this research. Indeed, the New Rice Fieldprint program has been implemented since 2006 to the present at the National level [6] while the district of the Mentawai Islands has just run this program in 2011 [5]. The new ricefield print aims to expand the raw rice field area in the various typology of land that has never been cultivated for agriculture with rice field system. It is expected to produce the New Rice Fieldprint, which has not formed the plow tread layer yet and have fulfilled the water requirements from the local water sources [7]. According to the interview results of the Head of Agriculture Department, the Mentawai Islands, implementing the New Rice Fieldprint program is not as easy as running a program in an area dominated by the mainland. There are several challenges/ obstacles faced so that some locations fail. The barriers faced in implementing this program include a short time of implementation, lack of cooperation between members of farmer groups, other work that must be completed by the local government such as; the construction of the Concrete Rebate road, profound knowledge of the farmer groups on the importance of expanding rice fields.

Those conditions are in line with the concept and policy theory, which state that the hardest thing lies in implementing the policies that have been made. Failure to enforce policies and development programs invites public concern because it causes financial loss (cost) that must be burdened by the community, it also eliminates opportunities for other systems needed by the city such as subsidies and grants. Implementation issues are not as easy as imagined. The implementation is a very complex activity that involves many actors with their various interests [8].

Until now, the implementation of the New Rice Fieldprint program in the district of the Mentawai Islands has not reached $100 \%$ of the target. The Implementation in 2011 was only able to create $50 \%$ of New Rice Fieldprint from $100 \mathrm{Ha}$ of the goal. According to the Department of Agriculture, Livestock and Plantation, the Mentawai Islands, until 2016, was the same period as 2011, which has not been able to achieve $100 \%$ of the target of the New Rice Fieldprint.

Referring to the facts that have been explained in this background, this research aims to identify and to clarify aspects related to the success and failure of implementing new rice fields mold in the district of the Mentawai Islands.

\section{MATERIALS AND METHOD}

This research is categorized as policy research, then the materials needed to conduct the study are related to the needs of data collection and data analysis. The materials used in this research were interview and questionnaire guidelines, and tools such as camera, sound recorder, and laptop. This research used a combination method of concurrent embedded strategy, which combined qualitative and quantitative methods simultaneously/ together, but the quality of each process was different. The qualitative methods were used to obtain primary data, while quantitative methods were used to collect supporting data [9-11]. The source of primary data derived from the interview results and questionnaires filled by 13 people who were directly used as research respondents. The technique used to determine the informants and research respondents were purposive techniques. The data focus of this research included aspects that implement the New Rice Fieldprint program success consist of:

- Qualified Human Resource

- Coordination on each institution and individual related to the policy/ program

- Facilities and infrastructure support

- Measurable program size and objectives

- Proactive communication among the program executors.

- Good bureaucratic structure

- The economic, social, and political support in the area where the program is implemented.

Besides, this research includes aspects that implement the New Rice Fieldprint program fail to consist of:

- Limited resources: human resources, costs, labor, material, and time.

- The target group (farmers) are not involved in program implementation

- The program implemented does not consider social, economic and political conditions

- Low capacity of human resources (government apparatus \& farmers)

- Absence of coordination and monitoring

- Implementation costs are higher than the problems to be resolved

- Geographical condition of the implemented program location.

The overall data focus above was analyzed by using quantitative descriptive techniques with the help of the rating scale method, which the raw data obtained in the form of numbers and then interpreted in a qualitative definition. Furthermore, the analysis results of the rating scale would be explained with descriptive qualitative methods through the help of interpretative analysis tools.

\section{RESULTS AND DISCUSSION}

\section{A. Preview of New Rice Fieldprint Program}

Agricultural development strategies are translated into concrete programs which conducted gradually and sustainably. The farm development program leads to the approach, vision, mission, and objectives of agricultural development. In principle, an excellent agrarian 
development program can overcome the problems and challenges faced in the agricultural sector [12].

Like the other challenges and problems of food security that are expected to be overcome by several agricultural development programs, one of them is the New Rice Fieldprint program. The New Rice Fieldprint program is an applicable translation of government policy to realize food security. This opinion is based on the understanding that the strategy tends to be more macro, normative, and abstract because the explanation is still general. This policy will be explained and elaborated again with a program that is smaller than the system, more technical, and not abstract. The program can be interpreted as a policy in terms of the objectives to be achieved. The program is a step to achieve the desired goal [13].

Many the functional shift of agricultural land to nonagricultural land causes the reduction of rice fields and decreases the productivity of rice in Indonesia. One of the alternative solutions proposed by the government is to run the expansion of rice fields. It aims to make the independence, sovereignty, and food security of the nation [14]. In practice, it cannot be separated from the synergy between ministry and government institutions, as shown in the following Table I:

TABLE I

THE SYNERGY OF GOVERNMENT INSTITUTIONS IN IMPLEMENTING THE NEW RICE FIELDPRINT PROGRAM IN INDONESIA.

\begin{tabular}{|l|l|l|}
\hline No & \multicolumn{1}{|c|}{$\begin{array}{c}\text { Government } \\
\text { Institutions }\end{array}$} & \multicolumn{1}{|c|}{ Challenge to overcome } \\
\hline 1. & $\begin{array}{l}\text { National Land } \\
\text { Agency dan Forestry }\end{array}$ & $\begin{array}{l}\text { Land availability used for expansion } \\
\text { of rice fields }\end{array}$ \\
\hline 2. & $\begin{array}{l}\text { Ministry of Public } \\
\text { Works }\end{array}$ & $\begin{array}{l}\text { Completion of necessary } \\
\text { infrastructure (Dams/reservoirs, } \\
\text { primary channels, secondary } \\
\text { channels, drainage canals, and } \\
\text { settlement streets) }\end{array}$ \\
\hline 3. & $\begin{array}{l}\text { Workshop } \\
\text { Coordinating Board }\end{array}$ & $\begin{array}{l}\text { Farmer assistance to cultivate new } \\
\text { rice fields }\end{array}$ \\
\hline 4. & $\begin{array}{l}\text { Ministry of } \\
\text { Manpower }\end{array}$ & $\begin{array}{l}\text { Preparation of transmigrants to } \\
\text { cultivate the new rice fields }\end{array}$ \\
\hline 5. & $\begin{array}{l}\text { Ministry of State- } \\
\text { Owned Enterprises }\end{array}$ & $\begin{array}{l}\text { Supplying seeds, fertilizers, } \\
\text { machinery, and other agricultural } \\
\text { facilities }\end{array}$ \\
\hline
\end{tabular}

The new rice field expansion program aims to expand the planting area and to increase the standard of agricultural land as one of the demands from the central government to support the national rice improvement program $(\mathrm{P} 2 \mathrm{BN})$ and rice self-sufficiency. In the new rice field expansion development, productivity will maximally be able to be seen in the next two to three years. However, this unique rice field is still below standard; the assumption for its productivity ranges from 2.5 tons to 3 tons per Ha. To increase productivity, the paddy/rice plant does not only depend on the land, but also water availability, land fertility, trainer support, capital support, and production facilities.

The implementation of the New Rice Fieldprint program has been started since 2006 by the Directorate General of Land and Water Management. The initial period of rice field expansion activities was the training season to related parties, both central and regional, of this program. Due to the new program, many associated parties are not yet familiar with the pattern of implementation. Many technical and administrative matters have not been mastered and understood well. These conditions often lead to the uncertainty of regional parties as event organizers in the field. Based on the Directorate General of Agricultural Infrastructure and Facilities, from 2010 until now, the New Rice Fieldprint program has been held by the first echelon called the Directorate General of Agricultural Infrastructure and Facilities. The development of land area volume of rice fields from 2006-2014 can be seen in Table II below.

TABLE II

VOLUME DEVELOPMENT OF RICE FIELD EXPANSION ACTIVITIES FROM 2006 TO 2014 IN INDONESIA.

\begin{tabular}{|l|l|l|}
\hline Year & Description & $\begin{array}{l}\text { Area } \\
\text { (Ha) }\end{array}$ \\
\hline $\begin{array}{l}2006- \\
2010\end{array}$ & $\begin{array}{l}\text { Rice field expansions of the Directorate } \\
\text { General of Land and Water Management } \\
\text { (PLA) }\end{array}$ & 69.102 \\
\hline 2011 & $\begin{array}{l}\text { Rice field expansions of the Directorate } \\
\text { General of Agricultural Facilities and } \\
\text { Infrastructure (PSP) }\end{array}$ & 62.100 \\
\hline 2012 & $\begin{array}{l}\text { Rice field expansions of the Directorate } \\
\text { General of Agricultural Facilities and } \\
\text { Infrastructure (PSP) }\end{array}$ & 100.000 \\
\hline $2013-$ & $\begin{array}{l}\text { Rice field expansions of the Directorate } \\
\text { General of Agricultural Facilities and } \\
\text { Infrastructure (PSP) }\end{array}$ & 200.000 \\
\hline
\end{tabular}

In 2013, a study of potential land for rice plant expansion in West Sumatra was done in South Pesisir and Tanah Datar District. The total possible area for the development of rice fields in the District of South Pesisir was $+17,156 \mathrm{Ha}$ $(2.84 \%)$ of the entire district area $+603,977 \mathrm{Ha}$. It consisted of very potential lands for the planting area expansion of rice fields for 10,355 $\mathrm{Ha}$, the potential lands with borders were 4,534 $\mathrm{Ha}$, the potential lands with a slope were 2,156 Ha, the possible areas with land borders and slope were $111 \mathrm{Ha}$. The potential areas to expand the rice fields in Tanah Datar District were $+203 \mathrm{Ha}(0.15 \%)$ of the total district area + $131,404 \mathrm{Ha}$. It consisted of very potential lands for the expansion of the rice field area of $28 \mathrm{ha}$, the potential lands with slope borders were $174 \mathrm{Ha}$.

The explanation above is one of the results made by the government as a basic implementation for the New Rice Fieldprint. These conditions relate to information and data on land availability in an area. Therefore, the government allocates budgets to conduct the Survey, Investigation, and Design (SID) activities as the initial stage before implementing the New Rice Fieldprint. Three things must absolutely be ascertained in the implementation of SID. First, is the legal ownership of land, right? Second, is the farmer's name registered real or just fictitious? Third, is the land proposed technically feasible for rice fields? [5].

For better implementation of New Rice Fieldprint activities, the government has published a book of Technical Guidance of Self-Managed Rice Field Expansion in 2017. The book explains some requirements for expanding the new rice fields, including land, water sources, and farmers. These three requirements must be fulfilled in advance by the regions that propose the original rice field print [14]. 
B. Aspects that Make Implementation of the New Rice Fieldprint Program Success

Regarding making the successful implementation of the new rice field print program in the Mentawai Islands, several needed aspects must be fulfilled by the government. There are several factors (issues) that can affect the success of implementing policy, such as size and objective of the plan, resources, characteristics of organizer, attitude of organizer, inter-organizational communication related to implementation, and social, economic and political environment. Its statement is not different from the one found in this research related to the aspects that can make the successful implementation of the New Rice Fieldprint program in the Mentawai Islands (see Table III).

TABLE III

ASPECTS THAT MAKE IMPLEMENTATION OF NEW RICE FIELDPRINT PROGRAM SUCCESS

\begin{tabular}{|c|c|c|c|c|c|}
\hline \multirow{2}{*}{$\begin{array}{c}\text { Aspects that Make Implementation of the New Rice } \\
\text { Fieldprint Program Success }\end{array}$} & \multicolumn{5}{|c|}{ Rating Value of Respondents } \\
\hline & $\begin{array}{c}\text { Very } \\
\text { Influential }\end{array}$ & Influential & $\begin{array}{c}\text { Quite } \\
\text { Influential }\end{array}$ & $\begin{array}{c}\text { Less } \\
\text { Influential }\end{array}$ & $\begin{array}{c}\text { Not } \\
\text { Influential }\end{array}$ \\
\hline Qualified human resources & 35 & - & - & - & - \\
\hline $\begin{array}{l}\text { Coordination on each institution and individual related to } \\
\text { the policy/ program. }\end{array}$ & - & - & 21 & - & - \\
\hline Facilities and infrastructure support & - & 28 & - & - & - \\
\hline Measurable size and objective of program & - & 28 & - & - & - \\
\hline Proactive communication among the program executors. & - & 28 & - & - & - \\
\hline Good bureaucratic structure & - & - & 21 & - & - \\
\hline $\begin{array}{l}\text { The economic, social and political support in the area where } \\
\text { the program is implemented }\end{array}$ & 35 & - & - & - & - \\
\hline
\end{tabular}

Refer to the data in Table III, and several aspects can make the implementation of the New Rice Fieldprint program in the Mentawai Island successful. The most influential elements are two aspects, which are qualified human resources and the existence of economic, social, and political support in the area where the policy/ program is implemented. Furthermore, the influential aspects of the successful implementation of the New Rice Fieldprint program are three aspects, which are facilities and infrastructure support, measurable program size and objectives, and proactive communication among executor of policies/ programs. Respondents position the other two elements in the ranking as quite influential, which are the present of coordination actions in each institution and individual related to policies/ programs and the excellent bureaucracy structure.

These findings are slightly different in a study revealed that the organization and management factors are the most critical categories in determining the success of policy implementation [15]. However, all aspects that can make the successful implementation of the New Rice Fieldprint program in the Mentawai Island District also require wellorganized and managed local government organizations (as a component in management).

From a project point of view, it revealed several factors that could influence the implementation of a project, including vision and strategy, government support, external pressure, and donor support, increased consumer expectations, technological change, modernization, and globalization [16]. Of course, the entire aspects contained in Table III are also somewhat like those expressed by [16]. However, to make the successful implementation of the new rice field program, support from all aspects is required.

\section{Aspects that Make the Implementation of the New Rice Fieldprint Program Fail}

Failed to implement the government policies or applications is not only found in Indonesia. Developing countries also find the same problems as in Nigeria; the adverse conditions of government and political bureaucracy become the factor that implements government programs fail [17]. It is also found in Jordan; several factors implement Jordanian government policies fail, including financial budgeting and costs, human expertise, social influence, technological problems, lack of awareness, resistance of public employees, privacy and security data, legal framework, technology needed, administrative barriers, and trust in products of government policy [18].

The factors (aspects) to implement government policies fail experienced by Nigeria and Jordan are also found in this research area (See Table IV). However, that aspect is quite different from the one that is experienced by the government of the Mentawai Islands.

According to the rating of respondents and research informants, the hugely influential aspects associated with the New Rice Fieldprint program fail are two aspects, which are limited resources: human resources, costs, energy, material and time, and geographical condition of the location. Next, the essential points are three aspects, which are the program implemented does not consider social, economic and political environmental conditions; Low capacity of human resources; and Implementation costs are higher than the problems that will be resolved. Besides, some aspects are quite influential on the failure of the implementation of the New Rice Fieldprint program, which is the target group (farmers) are not involved in program implementation and lack of coordination and monitoring. 
TABLE IV

ASPECTS THAT IMPLEMENT THE NEW RICE FIELDPRINT PROGRAM FAIL

\begin{tabular}{|c|c|c|c|c|c|}
\hline \multirow{2}{*}{$\begin{array}{l}\text { Aspects that implement the New Rice Fieldprint program } \\
\text { fail }\end{array}$} & \multicolumn{5}{|c|}{ Rating Value of Respondents } \\
\hline & $\begin{array}{c}\text { Very } \\
\text { Influential }\end{array}$ & Influential & $\begin{array}{c}\text { Quite } \\
\text { Influential }\end{array}$ & $\begin{array}{c}\text { Less } \\
\text { Influential }\end{array}$ & $\begin{array}{c}\text { Not } \\
\text { Influential }\end{array}$ \\
\hline $\begin{array}{l}\text { Limited resources: human resources, costs, labor, material, and } \\
\text { time. }\end{array}$ & 35 & - & - & - & - \\
\hline $\begin{array}{l}\text { The target group (farmers) are not involved in program } \\
\text { implementation }\end{array}$ & - & - & 21 & - & - \\
\hline $\begin{array}{l}\text { The implemented program does not consider social, economic } \\
\text { and political conditions }\end{array}$ & - & 28 & - & - & - \\
\hline $\begin{array}{l}\text { Low capacity of human resources (government apparatus \& } \\
\text { farmers) }\end{array}$ & - & 28 & - & - & - \\
\hline Absence of coordination and monitoring & - & - & 21 & - & - \\
\hline Implementation costs are higher than the problems to be solved & - & 28 & - & - & - \\
\hline Geographical condition of the implemented program location & 35 & - & - & - & - \\
\hline
\end{tabular}

\section{CONCLUSIONS}

Based on the results and discussions obtained from this research, some conclusions can be drawn about the aspects that make successful and failed implementation of the New Rice Fieldprint program in the Mentawai Islands. The elements that are very influential in shaping the success of implementing the New Rice Fieldprint program are qualified human resources and the existence of economic, social and political support in the area where the policy plans are implemented. Furthermore, three aspects are considered influential in making the program implementation success, such as support for facilities and infrastructure, measurable program size and objectives, and proactive communication among the implementer of policies/programs. However, several aspects implement New Rice Fieldprint program fail in Mentawai Islands, such as (a) Limited resources: human resources, costs, labor, materials and time; b) Geographical condition of the program implementation location; c) The program implemented does not consider social, economic and political environmental conditions; d) Low capacity of human resources (government apparatus \& farmers); e) Implementation costs are more significant than the problems that will be resolved.

\section{REFERENCES}

[1] Solahuddin, S. 2009. Pertanian Harapan Masa Depan Bangsa. IPB Press. Bogor.

[2] Subejo. 2012. Pembangunan Pertanian dan Pedesaan "Bunga Rampai". Universitas Indonesia Press (UI-Press). Jakarta.

[3] Saptana \& Ashari. 2007. Pembangunan Pertanian Berkelanjutan Melalui Kemitraan Usaha. Agricultural Research and Development Journal, Volume 26 Nomor 4, page 123-130

[4] Notohaprawiro, T. 2006. Pembangunan Pertanian Berkelanjutan Dalam Konteks Globalisasi dan Demokratisasi Ekonomi. Journal of Soil and Environment Science, Volume 6 Nomor 2, page 137-142.
[5] Directorate General of Agricultural Infrastructure and Facilities. 2013. Cetak Sawah, Indonesia. Ministry of Agriculture of the Republic of Indonesia. Jakarta.

[6] Panudju, I.T et al., 2013. Cetak Sawah, Indonesia. Directorate of Land Expansion and Management and Directorate General of Agricultural Infrastructure and Facilities. Jakarta.

[7] Ministry of Agriculture. 2016. Pedoman Teknis Survei dan Investigasi Calon Petani-Calon Lokasi dan Pemetaan Desain Perluasan Sawah Tahun 2016. Directorate of Land Expansion and Management and Directorate General of Agricultural Infrastructure and Facilities. Jakarta.

[8] Purwanto, A.E \& Sulistyastuti, R.D. 2012. Implementasi Kebijakan Publik Konsep dan Aplikasinya di Indonesia. Gava Media Publisher. Yogyakarta.

[9] J. W. Creswell, Educational Research: Planning, Conducting, and Evaluating Quantitative and Qualitative Research. Pearson, 2012.

[10] J. W. Creswell and J. D. Creswell, Research design: Qualitative, quantitative, and mixed methods approaches. Sage publications, 2017.

[11] Tashakkori, A \& Teddlie, C. 2010. Handbook of Mixed Methods in Social \& Behavioral Research. Library of Students. Yogyakarta.

[12] Nuhung, A.I. 2014. Strategi \& Kebijakan Pertanian dalam Perspektif Daya Saing. Rineka Cipta. Jakarta.

[13] Sumodiningrat, G. 2000. Pembangunan Ekonomi melalui Pengembangan Pertanian. Bina Rena Pariwara LCC (First Edition). Jakarta.

[14] Direktorat Jenderal Prasarana dan Sarana Pertanian, "Pedoman Teknis Pelaksanaan Perluasan Sawah Pola Swakelola 2017.” p. 66, 2017.

[15] Vaidya, K., A.S.M. Sajeev., Callender, G. 2006. Critical Factors That Influence E-Procurement Implementation Success in The Public Sector. Journal of Public Procurement, Volume 6, Issues $1 \& 3,70-$ 99

[16] Gichoya, D., 2005. Factors Affecting the Successful Implementation of ICT Projects in Government. Journal of e-Government Volume 3 Issue 4, pp 175-184, available online at www.ejeg.com.

[17] Bolaji, D.S., Gray, R.J., Campbell-Evans, G. 2015. Why Do Policies Fail in Nigeria? Journal of Education \& Social Policy, Vol. 2, Num. 5; November 2015, 57-66.

[18] M. Al-Shboul, O. Rababah, R. Ghnemat, and S. Al-Saqqa, "Challenges and factors affecting the implementation of egovernment in Jordan," J. Softw. Eng. Appl., vol. 7, no. 13, p. 1111, 2014. 